\title{
PENINGKATAN PRETASI BELAJAR IPS MENGGUNAKAN TIPE NUMBERED HEADS TOGETHER (NHT) PADA SISWA KELAS VI SD NEGERI DASAN BARU JABON TAHUN 2015/2016
}

\author{
Lalu Tauhid \\ Guru SDN Dasan Baru Jabon, tauhidlalu@gmail.com
}

INFO ARTIKEL
Riwayat Artikel:
Diterima: 18-03-2018
Disetujui: $05-04-2018$

Kata Kunci:

Numbered Heads Together (NHT), IImu Pengetahuan sosial.

\section{A. LATAR BELAKANG}

Untuk meningkatkan prestasi belajar siswa, tentunya tidak lepas dari upaya peningkatan kualitas pembelajaran di sekolah. Berlakunya Kurikulum 2004 berbasis kompetensi yang telah direvisi melalui Kurikulum Tingkat Satuan Pendidikan menuntut perubahan paradigma dalam pendidikan dan pembelajaran. Keberhasilan pembelajaran dalam arti tercapainya tujuan intruksional sangat bergantung pada kemampuan guru dalam mengelola proses belajar mengajar. Guru sebagai komponen utama yang menentukan suksesnya kegiatan pembelajaran ditunut untuk dapat memilih dan menggunakan metode-metode atau tehnik-tehnik atau mengajar yang tepat dalam menyampaikan materi pembelajaran.

Salah satu masalah pokok dalam pembelajaran Ilmu Pengetahuan SosiaL di Sekolah Dasar Negeri Dasan Baru Jabon adalah rendahnya prestasi belajar Ilmu Pengetahuan Sosial. Hal ini terlihat pada rerata hasil belajar Ilmu Pengetahuan Sosial yang masih rendah.

Guru lebih suka menggunakan metode ceramah sebab tidak memerlukan alat dan bahan praktik, cukup menjelaskan konsep-konsep yang ada pada buku ajar. Dalam hal ini siswa tidak diajarkan strategi yang dapat memahami bagaimana belajar, berpikir, dan memotivasi diri sendiri. Kondisi pembelajaran seperti ini berdampak pada hasil belajar Ilmu Pengetahuan Sosial siswa VI yaitu dengan tidak tercapainya Kriteria Ketuntasan Minimal (KKM) mata pelajaran Ilmu Pengetahuan Sosial yang telah di tetapkan pada Kurikulum Tingkat Satuan Pendidikan (KTSP) Sekolah Dasar Negeri Dasan Baru Jabon tahun pelajaran 2009-2010 sebesar 65. Selain itu hasil analisis pelajaran Ilmu Pengetahuan Sosial Kelas VI semester II (Dua) tahun pelajaran 2009-2010 menunjukkan bahwa dari 25 orang siswa hanya 8 siswa yang telah mencapai KKM (32 \%) dan 17 siswa belum mencapai KKM dengan nilai rata-rata siswa adalah 6,16. Penyebab rendahnya prestasi hasil belajar Ilmu Pengetahuan Sosial siswa tersebut antara lain :

1. Selama ini guru cenderung menggunakan metode konvensional yang didominasi oleh metode ceramah.

2. Pengamatan langsung terhadap obyek yang sedang dipelajari sangat kurang.

3. Penggunaan media dalam proses pembelajaran sangat kurang.

Untuk meningkatkan prestasi belajar perlu alternatif pendekatan pembelajaran yang tepat dan sesuai untuk digunakan guru. Adapun pendekatan-pendakatan yang dugunakan untuk meningkatkan prestasi siswa 
khususnya dalam mata pelajaran Ilmu Pengetahuan Sosial di Sekolah Dasar Negeri Dasan Baru Jabon adalah dengan menggunakan strategi pembelajaran kooperatif tipe Numbered Heads Together (NHT) agar prestasi belajar siswa lebih optimal.

Pembelajaran tipe Numbered Heads Together (NHT) dipilih untuk memperbaiki pembelajaran Ilmu Pengetahuan Sosial (IPS) karena :

1. Dapat meningkatkan rasa tanggung-jawab siswa dalam belajar.

2. Melatih siswa untuk percaya diri.

3. Keaktifan belajar siswa meningkat

4. Penguasaan materi pelajaran oleh siswa lebih merata.

Dari latar belakang tersebut diatas, maka dirumuskan permasalah sebagai berikut: "Bagaimanakah Peningkatan Prestasi Belajar Ilmu Pengetahuan Sosial Menggunakan Tipe Numbered Heads Together (NHT) Pada Siswa Kelas VI Sekolah Dasar Negeri Dasan Baru Jabon Tahun 2015/2016.

\section{B. METODE PENELITIAN}

\section{Rencana tindakan}

Rencana tindakan penelitian ini melalui beberapa tahap yaitu, tahap Perencanaan, Pelaksanaan tindakan, Observasi, dan Refleksi. Siklus pelaksanaannya dapat digambarkan sebagai berikut :

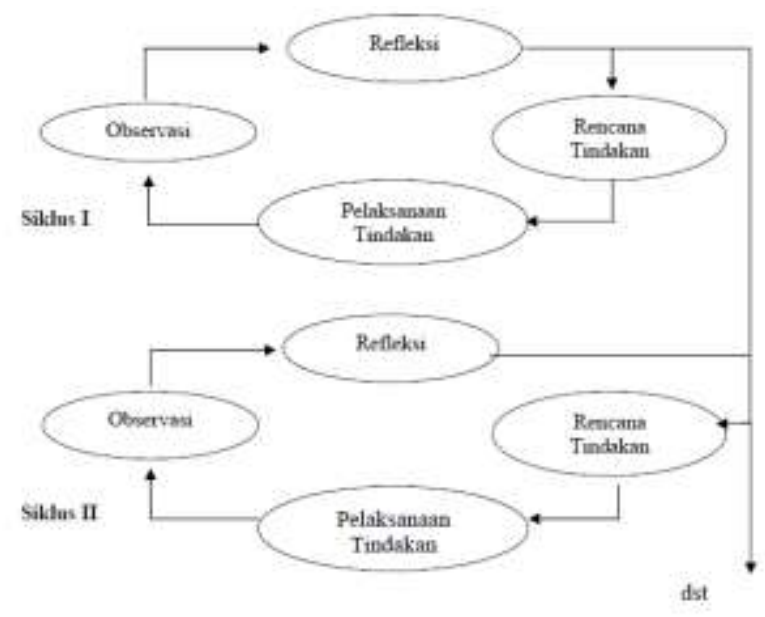

Gambar 1 Alur Pelaksanaan Tindakan Kelas

(Sumber : Aunurrahman, dkk 2010)

Untuk melaksanakan PTK dengan kajian pembelajaran tipe Numbered Heads Together (NHT) ini direncanakan tindakan dengan langkahlangkah sebagai berikut :

\section{SIKLUS I}

\section{a. Perencanaan Siklus I :}

Tahap perencanaan yang dilaksanakan dalam penelitian ini adalah sebagai berikut:

1) Penyusunan RPP (lampiran 1)
2) Menyiapkan sarana dan prasana pembelajaran sesuai dengan materi dan tipe Numbered Heads Together (NHT).

3) Menyiapkan lembar observasi untuk siswa dan guru. (lampiran 3,4)

4) Menyusun alat evaluasi. (lampiran 5)

b. Pelaksanaan Tindakan Siklus I

1) Kegiatan Pendahuluan

2) Guru menginformasikan model pembelajaran yang akan digunakan yaitu tipe Numbered Heads Together (NHT).

3) Guru menginformasikan tujuan pembelajaran.

4) Guru membagi kelompok kecil yaitu 4-5 orang.

5) Motivasi.

6) Kegiatan Inti

7) Siswa dibagi dalam kelompok, setiap kelompok terdiri atas 5 orang.

8) Masing-masing kelompok mendapatkan LKS tentang gejala alam yang terjadi di Indonesia dan Negara tetangga.

9) Masing-masing anggota kelompok mengerjakan tugas sesuai dengan nomor dada yang dipasang.

10) Guru membuka pertanyaan kepada seluruh peserta didik dalam kelas. Peserta didik yang nomor dada satu (misalnya) diminta untuk mengankat tangan.

11)Guru menunjuk peserta didik yang mengangkat tangan untuk mempresentasikan hasil kerjasama dalam kelompok, peserta didik yang lain memperhatikan dan menanggapi dalam kegiatan diskusi.

12) Penutup

13)Guru bersama siswa menyimpulkan hasil pembelajaran dan membuat rangkuman materi.

14)Guru memberikan tugas

\section{c. Observasi}

Observasi pembelajaran dilaksanakan dengan menggunakan format obervasi dan memberikan catatan-catatan tertentu yang berkaitan dengan proses pembelajaran. Hasil observasi tersebut selanjutnya direkapitulasi dalam tabel data yang telah disediakan yang selanjutnya didiskusikan dengan teman-teman guru interpretasinya sebagai bahan perbaikan.

\section{d. Evaluasi}

Evaluasi belajar siswa dilakukan tiap siklus dengan memberikan tes pilihan ganda.

\section{e. Refleksi}

Penelitian tindakan kelas ini dilaksanakan dalam 2 siklus, dan masing-masing siklus diikuti 
dengan analisis dan refleksi sebagai bahan perbaikan.

\section{SIKLUS II}

Pada siklus II ini dilakukan tahapan-tahapan seperti pada siklus pertama tetapi didahului dengan perencanaan untuk memperbaiki kekurangan pada pembelajaran siklus pertama dari segi perencanaan maupun pelaksanaan tindakan yang diketahui dari tes evaluasi belajar siswa yang telah dianalisis.

\section{Instrumen Penelitian}

Intrumen penelitian dibuat untuk keperluan pengumpulan data. Adapun instrumen yang dugunakan dalam penelitian ini adalah sebagai berikut:

a. Lembar Observasi

Lembar observasi digunakan untuk memperoleh gambaran tentang proses pembelajaran tipe Numbered Heads Together (NHT) yang berkaitan dengan aktivitas guru dan siswa selama proses pembelajaran.

b.

Tes hasil belajar

Untuk mengukur kemampuan kognitif siswa, siswa diberikan tes pilihan ganda.

\section{Tehnik Pengumpulan Data}

a. Data prestasi belajar siswa

Data prestasi belajar siswa, dikumpulkan dengan memberikan tes pilihan ganda. Tes diberikan pada tiap akhir siklus.

b. Data Aktivitas Guru dan Siswa

Data aktivitas guru dan siswa dikumpulkan dengan menggunakan metode observasi. Instrumen yang digunakan adalah lembar observasi.

\section{Analisis Data}

Untuk menganalisis data dalam penelitian ini adalah dengan melakukan reduksi data yaitu melakukan klasifikasi, memilah dan memilih datadata yang diperlukan dan membuang data-data yang tidak diperlukan yang diperoleh dari hasil refleksi secara kolaborasi. Selanjutnya melakukan paparan data yaitu memaparkan atau menyajikan data-data hasil reduksi dan seterusnya dilakukan interprestasi atau pemberian makna terhadap data-data hasil sajian dan membuat simpulan untuk melakukan perbaikan pembelajaran pada siklus berikutnya. Untuk menjaga keakuratan dan kelengkapan data dalam penelitian ini dengan menggunakan riangulasi metode yaitu dengan melakukan pengecekan ulang informasi dari hasil pengamatan dan tes akhir tindakan dengan menggunakan metode yang sama.

Ada dua katagori untuk ketuntasan belajar yaitu secara perorangan atau individu dan secara klasikal. Untuk kurikulum Tingkat Satuan Pendidikan (KTSP), yang menjadi tolak ukur tuntas tidaknya kegiatan pembelajaran pada suatu mata pelajaran dapat dilihat pada Kriteria Ketuntasan Minimal (KKM) yang telah ditetapkan sebelumnya, dan untuk mata pelajaran Ilmu Pengetahuan Sosial KKM pada semester II di Sekolah Dasar Negeri Dasan Baru Jabon adalah 65 .

\section{Indikator Kinerja.}

Penelitian ini dikatakan berhasil apabila :

a. Pembelajaran dengan model kooperatif tipe Numbered Heads Together (NHT) dapat dilaksanakan secara optimal, yaitu minimal $80 \%$ indikator dalam lembar pengamatan tercapai.

b. Siswa disebut memiliki prestasi belajar atau berhasil dalam proses kegiatan belajar mengajar apabila masing-masing siswa telah memperoleh nilai minimal 65\%. Sedangkan secara klasikal disebut berhasil atau tuntas belajar apabila minimal $85 \%$ dari siswa yang telah memperoleh nilai minimal $65 \%$.

\section{HASIL DAN PEMBAHASAN}

\section{Hasil Penelitian}

Penelitian Tindakan kelas ini dilaksanakan di kelas VI Sekolah Dasar Negeri Dasan Baru Jabon Desa Bagu Kecamatan Pringgarata Kabupaten Lombok Tengah Tahun Pelajaran 2010 / 2011 dengan jumlah siswa seluruhnya182 orang yang terdidri dari 88 siswa laki-laki dan 94 orang siswa perempuan terdiri 6 kelas. Kelas VI berjumlah 25 orang ,laki-laki 8 orang dan perempuan 17 orang.

Penelitian ini berlangsung 2 Siklus, masingmasing siklus terdiri dari beberapa tahap yaitu perencanaan, tindakan, diagonasis/observasi dan tahap refleksi/evaluasi.

\section{1) Siklus I}

\section{a. Pelaksanaan Tindakan}

Penelitian Tindakan kelas ini dilaksanakan di kelas VI Sekolah Dasar Negeri Dasan Baru Jabon Desa Bagu Kecamatan Pringgarata Kabupaten Lombok Tengah Tahun Pelajaran 2010/ 2011. Adapun untuk melaksanaan PTK dengan kajian pembelajaran tipe NHT pada siklus I diadakan dua kali pertemuan, masingmasing pertemuan dilaksanakan 2x35 menit dengan materi gejala (peristiwa) alam yang terjadi di Indonesia dan negara tetangga berlangsung. Sedangkan evaluasi dilaksanakan pada akhir pertemuan kedua. 


\section{b. Hasil Observasi Kegiatan Guru}

TABEL 2

KEGIATAN GURU PADA SIKLUS I

\begin{tabular}{|c|l|c|c|}
\hline No & \multicolumn{1}{|c|}{ Indikator } & Skor & Kreteria \\
\hline 1 & Pra Pembelajaran & & \\
\hline 2 & $\begin{array}{l}\text { Membuka } \\
\text { Pembelajaran }\end{array}$ & 3 & \\
\hline 3 & $\begin{array}{l}\text { Kegiatan Inti } \\
\text { Pembelajaran }\end{array}$ & & \\
\hline \multirow{7}{*}{} & $\begin{array}{l}\text { A. Penguasaan materi } \\
\text { pelajaran }\end{array}$ & 2,75 & \\
\cline { 2 - 4 } & $\begin{array}{l}\text { B. } \\
\text { Pendekatan/strategi } \\
\text { pembelajaran }\end{array}$ & 2,85 & \\
\cline { 2 - 4 } & $\begin{array}{l}\text { C. Pemanfaatan } \\
\text { media } \\
\text { pembelajaran/sumber } \\
\text { belajar }\end{array}$ & 3,5 & \\
\cline { 2 - 4 } & $\begin{array}{l}\text { D. Pembelajaran yang } \\
\text { menantang dan } \\
\text { memacu } \\
\text { keterlibatan siswa }\end{array}$ & 3,16 & \\
\hline & $\begin{array}{l}\text { E. Penilaian proses } \\
\text { dan hasil belajar }\end{array}$ & 3,5 & \\
\cline { 2 - 4 } & $\begin{array}{l}\text { F. Penggunaan } \\
\text { bahasa }\end{array}$ & 3,66 & \\
\hline 5 & Penutup & 2,6 & \\
\hline
\end{tabular}

Kegiatan guru selama pembelajaran berlangsung dapat diketahui dari lembar observasi guru (lampiran 3) berdasarkan hasil analisis kegiatan mengajar guru di peroleh skor sebesar 3,09 dan tergolong baik. Dari hasil observasi mengajar dapat diproleh data sebagai berikut:

a) Guru kurang menyampaikan tujuan pembelajaran

b) Guru kurang menguasi kelas

c) Pengaturan waktu yang kurang tepat

Berdasarkan analisis aktivitas belajar siswa diperoleh skor aktivitas siswa 3,35 dengan kreteria baik.

Adapun kekurangan yang dicapai pada siklus I adalah sebagai berikut:

a) Siswa kurang senang dalam mengikuti pembelajaran karena siswa secara langsung tidak dapat menyebutkan gejala/faktor penyebab terjadinya bencana dan cara menyelamatkan korban bencana peristiwa alam yang pernah terjadi di Indonesia dan negara tetangga. b) Guru kurang baik dalam melakukan perannya sesuai perencanaan selama proses pembelajaran

c) Ada materi yang belum dapat difahami maksimal oleh siswa karena perencanaan materi yang akan dipelajari terlalu luas.

\section{d. Hasil Evaluasi}

Evaluasi dilaksanakan pada tiap akhir siklus yaitu pada pertemuan kedua. Guru memberikan soal evaluasi sebanyak 10 soal dalam bentuk pilihan ganda yang dikerjakan dalam waktu 2x35 menit data hasil evaluasi siklus I dapat dilihat pada table berikut:

TABEL 3

DATA HASIL EVALUASI BELAJAR SIKLUS I

\begin{tabular}{|l|l|}
\hline \multicolumn{1}{|c|}{ INDIKATOR } & \multicolumn{1}{c|}{ JUML } \\
& LAH \\
\hline Nilai tertinggi & 90 \\
Nilai terendah & 50 \\
Jumlah siswa yang ikut tes & 25 orang \\
Rata-rata kelas & 7,28 \\
Ketuntasan belajar & $72,00 \%$ \\
Banyak siswa yang tidak & 7 orang \\
tuntas & \\
\hline
\end{tabular}

Beradasarkan hasil analisis data yang diperoleh pada siklus I adalah sebagai berikut, rata-rata klasikal ketercapaian nilai siswa adalah 7,28 sehingga dapat dikatakan mencapai katagori baik, perolehan nilai tertinggi 90 perolehan nilai terendah 50, prosentase ketuntasan $72,00 \%$ terdapat $28,00 \%$ siswa yang belum mencapai (Hasil lengkap pada lampiran 6).

\section{e. Refleksi}

Dari hasil Evaluasi dan observasi proses pembelajaran pada siklus I adalah:

1) Siswa kurang senang dalam mengikuti pembelajaran karena siswa secara langsung tidak dapat menyebutkan gejala/faktor penyebab terjadinya bencana dan cara menyelamatkan korban bencana peristiwa alam yang pernah terjadi di Indonesia dan negara tetangga.

2) Guru kurang baik dalam melakukan perannya sesuai perencanaan selama proses pembelajaran

3) Ada materi yang belum dapat difahami maksimal oleh siswa karena perencanaan materi yang akan dipelajari terlalu luas.

Adapun hal-hal yang perlu diperbaiki adalah: 
(1). Pemanfaatan waktu yang tersedia agar lebih optimal

(2). Yang menjadi fokus tujuan pembelajaran adalah tercapainya target nilai atau KKM bukan senang dalam proses pembelajaran

(3). Keluasan materi yang direncanakan sesuai dengan waktu yang tersedia.

\section{SIKLUS II}

\section{a. Pelaksanaan Tindakan}

Penelitian Tindakan kelas ini dilaksanakan di kelas VI Sekolah Dasar Negeri Dasan Baru Jabon Desa Bagu Kecamatan Pringgarata Kabupaten Lombok Tengah Tahun Pelajaran 2010/ 2011. Adapun untuk melaksanaan PTK dengan kajian pembelajaran tipe Numbered Heads Together (NHT) pada siklus I diadakan dua kali pertemuan, masingmasing pertemuan dilaksanakan 2x35 menit dengan materi mengenal cara-cara mengahdapi benca alam. Sedangkan evaluasi dilaksanakan pada akhir pertemuan kedua.

\section{b. Hasil Observasi Kegiatan Guru}

Kegiatan guru selama pembelajaran berlangsung dapat diketahui dari lembar observasi guru (lampiran 9) berdasarkan hasil analisis kegiatan mengajar guru di peroleh skor sebesar 34 dan tergolong baik. Dari hasil observasi mengajar dapat diproleh data sebagai berikut:
1) Guru kurang menyampaikan tujuan pembelajaran
2) Guru kurang menguasi kelas
3) Pengaturan waktu yang kurang tepat

\section{c. Aktifitas siswa}

Berdasarkan analisis aktivitas belajar siswa diperoleh skor aktivitas siswa 3,75, tergolong baik. Adapun kekurangan yang dicapai pada siklus II adalah sebagai berikut:

1) Siswa kurang senang dalam mengikuti pembelajaran karena siswa secara langsung tidak dapat menyebutkan gejala/faktor penyebab terjadinya bencana dan cara menyelamatkan korban bencana peristiwa alam yang pernah terjadi di Indonesia dan negara tetangga.

2) Guru kurang baik dalam melakukan perannya sesuai perencanaan selama proses pembelajaran

3) Ada materi yang belum dapat difahami maksimal oleh siswa karena perencanaan materi yang akan dipelajari terlalu luas.

Evaluasi dilaksanakan pada tiap akhir siklus yaitu pada pertemuan kedua. Guru memberikan soal evaluasi sebanyak 10 soal dalam bentuk pilihan ganda yang dikerjakan dalam waktu 2x35 menit (lampiran 12) data hasil evaluasi siklus II dapat dilihat pada table berikut:

\section{d. Hasil Evaluasi}

TABEL 4

DATA HASIL EVALUASI BELAJAR SIKLUS II

\begin{tabular}{|l|l|}
\hline INDIKATOR & JUMLLAH \\
\hline Nilai tertinggi & 100 \\
Nilai terendah & 60 \\
Jumlah siswa yang ikut tes & 25 orang \\
Rata-rata kelas & 8,56 \\
Ketuntasan belajar & $96,00 \%$ \\
Banyak siswa yang tidak tuntas & 1 orang \\
\hline
\end{tabular}

Hasil analisis data yang diperoleh pada siklus II pertemuan I adalah sebagai berikut, rata-rata klasikal ketercapaian nilai siswa adalah 8,56 sehingga dapat dikatakan mencapai katagori baik, perolehan nilai tertinggi 100, perolehan nilai terendah 60, prosentase ketuntasan 96\%, siswa yang belum mencapai KKM 1 orang atau 4\%

Hasil observasi para observer yang merekam seluruh proses pembelajaran bahwa:

1) Semua pertanyaan yang diajukan oleh guru saat pembelajaran dapat dijawab oleh siswa karena mereka langsung mengamati pada monitor

2) Semua siswa aktif, ada yang membuka atlas, peta, dan globe untuk mecari penyelesaian permasalahan yang ditugaskan

3) Siswa merasakan kebebasan untuk maju ke materi berikutnya apabila telah menyelesaikan tugas karena masing-masing kelompok sedah mengerti.

4) Terlihat senang di wajah para siswa selama mengikuti pembelajaran

5) Semua materi dapat terselesaikan

6) Guru telah melakukan perannya sebagai pasilitator bukan pengajar.

Penelitian tindakan kelas ini dilakukan untuk meningkatkan kualitas proses dan hasil belajar siswa pada materi pembelajaran MendeskrIlmu Pengetahuan Sosialikan gejala (peristiwa) alam yang terjadi di Indonesia dan negara tetangga. serta Mengenal cara-cara menghadapi bencana alam. Penelitian tindakan kelas ini terdiri dari 2 siklus. Dalam setiap siklus terdiri dari empat tahap, yaitu perencanaan, pelaksanaan tindakan, evaluasi dan refleksi.

Hasil analisis data yang diperoleh pada siklus I adalah sebagai berikut, rata-rata klasikal nilai siswa adalah 7,28 sehingga dapat dikatakan mencapai katagori cukup baik, perolehan nilai tertinggi 90 perolehan nilai terendah 50, persentase ketuntasan $72 \%$ terdapat $28 \%$ siswa yang belum mencapai ketuntasan belajar.

Hasil observasi proses pembelajaran pada siklus I 
adalah:

1) Siswa kurang senang dalam mengikuti pembelajaran karena siswa secara langsung tidak dapat menyebutkan gejala/faktor penyebab terjadinya bencana dan cara menyelamatkan korban bencana peristiwa alam yang pernah terjadi di Indonesia dan negara tetangga.

2) Guru kurang baik dalam melakukan perannya sesuai perencanaan selama proses pembelajaran

3) Ada materi yang belum dapat difahami maksimal oleh siswa karena perencanaan materi yang akan dipelajari terlalu luas.

Adapun hal-hal yang perlu diperbaiki adalah:

1) Pemanfaatan waktu yang tersedia agar lebih optimal

2) Yang menjadi fokus tujuan pembelajaran adalah tercapainya target nilai atau KKM bukan senang dalam proses pembelajaran

3) Keluasan materi yang direncanakan sesuai dengan waktu yang tersedia

Hasil analisis data yang diperoleh pada siklus II adalah sebagai berikut, rata-rata klasikal ketercapaian nilai siswa adalah 8,56 sehingga dapat dikatakan mencapai katagori baik, perolehan nilai tertinggi 100, perolehan nilai terendah 60 , prosentase ketuntasan $96 \%$, siswa yang belum mencapai ketuntasan $4 \%$

Hasil observasi para observer yang merekam seluruh proses pembelajaran bahwa:

2) Semua pertanyaan yang diajukan oleh guru saat pembelajaran dapat dijawab oleh siswa karena mereka langsung mengamati pada monitor

3) Semua siswa aktif, ada yang mencari korang dan lain-lain untuk mecari penyelesaian permasalahan yang ditugaskan

4) Siswa merasakan kebebasan untuk maju ke materi berikutnya apabila telah menyelesaikan tugas karena masing-masing kelompok belajar dengan serius.

5) Terlihat senang di wajah para siswa selama mengikuti pembelajaran

6) Semua materi dapat terselesaikan

7) Guru telah melakukan perannya sebagai pasilitator bukan pengajar.

Secara keseluruhan hasil penelitian ini menunjukkan bahwa penggunaan pembelajaran tipe Numbered Heads Tigether (NHT) dapat dikatakan berhasil meningkatkan prestasi belajar terlihat pada peningkatan kualitas proses dan hasil belajar dimana nilai rata-rata siswa pada materi memahami gejala/pristiwa alam yang terjadi di Indonesia dan Negara tetangga serta mengenal cara-cara menghadapi bencana alam terlihat dari nilai rata-rata klasikal ketercapaian nilai siswa dua siklus berturut-turut, siklus pertama $72 \%$ dan siklus kedua $96 \%$.
Menurut Suwiyadi (dalam Dwitasari, 2006), proses pembelajaran yang menggunakan pembelajaran tipe Numbered Heads Tigether (NHT) merupakan suatu strategi pembelajaran dengan cara 1). Penomoran (numbering), pada tahap ini guru membagi peserta didik menjadi beberapa kelompok atau tim yang beranggotakan tiga hingga lima orang dan memberi mereka nomor sehingga setiap peserta didik dalam tim tersebut memiliki nomor yang berbeda. Pemberian nomor untuk memudahkan kinerja kelomopok, mengubah posisi kelompok, menyusun materi pembelajaran, mempresentasikan, dan mendapatkan tanggapan dari kelompok lain.2). Pengajuam pertanyaan (questioning), pada tahap ini guru mengajukan pertanyaan kepada peserta didik; 3). Berpikir bersama (heads together), pada tahap ini peserta didik berpikir bersama untuk menggambarkan dan meyakinkan bahwa setiap orang mengetahui jawaban tersebut; dan 4). Pemberian jawaban (answering), pada tahap ini guru menyebut satu nomor peserta didik yang memiliki nomor yang sama dari setiap kelompok mengangkat tangan dan menyiapkan jawaban untuk seluruh kelas.

Strategi pembelajaran tipe numbered heads together (NHT) mampu membuat peserta didik lebih bertanggung jawab terhadap hasil belajar karena mereka termotivasi dengan tugas-tugas yang harus diselesaikan berdasarkan nomor yang mereka miliki.

Jadi penggunaan pembelajaran tipe numbered heads together (NHT) dapat meningkatkan prestasi belajar Ilmu Pengetahuan Sosial pada siswa kelas VI Sekolah Dasar Negeri Dasan Baru Jabon pada semester II tahun ajaran 2015/2016.

\section{SIMPULAN DAN SARAN}

Berdasarkan kesimpulan diatas, tersapat beberapa saran yang diajukan kepada pihak-pihak yang terkait dengan penelitian ini, yaitu:

Bagi guru; Hendaknya dalam pembelajaran menggunakan tipe Numbered Heads Together (NHT) karena terbukti dari hasil penelitian menunjukkan peningkatan prestasi belajar siswa yang sangat optimal.

Tingkatkan profesionalisme guru dalam melaksanakan pembelajaran dengan baik. Bagi pengawas; agar melakukan sosialisasi kepada para guru, terkait dengan penggunaan tipe Numbered Heads Together (NHT).

Bagi sekolah: supaya lebih banyak mengalokasikan dana untuk melengkapi media pembelajaran. 


\section{UCAPAN TERIMA KASIH}

Dengan penuh rasa hormat, saya ucapkan teimakasih kepada:

Kepala Dinas Pendidikan Kabupaten Lombok Tengah yang telah memfasilitasi, mengizinkan penulis untk mengadakan penelitian hingga dapat terlaksana dengan baik.

Bapak Pengurus PGRI Kec. Pringgarata dan Ketua Gugus yang telah menfasilitasi dalam seminar hasil penelitian Guru-guru Kecamatan Pringgarata.

\section{DAFTAR RUJUKAN}

[1] BSNP, 2006. Panduan Penyusunan Kurikulum Tingkat Satuan Pendidikan Jenjang Pendidikan Dasar dan Menengah. Jakarta, Depdiknas.

[2] Burhanuddin, 2005 Standar Penilaian Kelas. Departemen Agama RI Direktorat Jenderal Kelembagaan Agama Islam.Jakarta. Direktorat Madrasah dan Pendidikan Agama Islam Pada Sekolah Umum.

[3] Djauzak Ahmad, 1996. Petunjuk Peningkatan Mutu Pendidikan di Sekolah Dasar. Jakata, Departemen Pendidikan dan Kebudayaan, Derektorat Jendral Pendidikan Dasar dan Menengah Direktorat Pendidikan Dasar.

[4] Dwitasari Yuyun,2002. Strategi-strategi Pembelajaran untuk Penelitian Tindakan Kelas. Bandung; Pena Gemilang.

[5] Ermayanti, Siti. 2006. Penerapan Model Pembelajaran Kooperatif Tipe Teams-Games-Tournament pada Pokok Bahasan Perbandingan sebagai Upaya Meningkatkan Hasil belajar dan Aktivitas Siswa Kelas IA SMP Negeri 2 Pujut Tahun Pelajaran 2005/2006. Skripsi. Universitas Mataram.

[6] Kurnia, dkk, 2007. Perkembangan Belajar Peserta Didik. Jakarta, Derektorat Jendral Pendidikan Tinggi Kementrian Pendidikan Nasional.

[7] Poerwadarminta, 2003. Kamus Umum Bahasa Indonesia. Jakarta, Balai Pustaka.

[8] Siddiq Djauhar; Munawaroh Isniatun; Sungkono, 2009. Pengembangan Bahan Pembelajaran SD, Jakarta, Direktorat Pendidikan Tinggi Departemen Pendidikan Nasional.

[9] Soekirman, 2010, Panduan Pemantapan Praktik Lapangan Jakarta, Derektorat Jendral Pendidikan Tinggi Kementrian Pendidikan Nasional.

[10] Sudirman. 2010. Penerapan Pembelajaran Kontekstula Dalam Meningkatkan Prestasi Belajar Matematika Pada Siswa Kelas VII MTS Hadil Ishlah Bilebante Tahun Pelajaran 2009/2010. Skripsi. Universitas Nahdlatul Wathan Mataram.

[11] Taneo, dkk, 2010. Kajian IPS SD Jakarta, Direktorat Pendidikan Tinggi Departemen Pendidikan Nasional. 